\title{
The Effect of Landscape Trees on Residential Property Values of Six Communities in Cincinnati, Ohio
}

\author{
Kelley C. Dimke, T. Davis Sydnor, and David S. Gardner
}

\begin{abstract}
The value of the urban forest as a component of the urban environment is significant. Trees provide both environmental and social benefits to urban dwellers. In many cities, financial support for urban forestry is on the decline. The objective of this research was to evaluate the impact trees have on property values of six communities (Bond Hill, Carthage, Clifton, Hyde Park, Kennedy Heights, and North Avondale) of varying socioeconomic levels in Cincinnati, Ohio, U.S. Tax assessor records were obtained for property sales between the years 2000 and 2005. One hundred sites were randomly selected from each of the six communities. Data were collected from each site during the winter as well as the summer months. Dominant genus, caliper of dominant genus, estimate of tree cover, and overall property maintenance were recorded. The hedonic method was used for this analysis. The average (mean) effect of tree canopy across all six communities was an increase of approximately USD $\$ 780$ per one percent increase in tree cover. The mean sale price across the 600 sites was $\$ 188,730$; the mean canopy cover was $25.8 \%$. This indicates the average value of tree canopy is $\$ 20,226$ or $10.7 \%$ of the sale price of the home.

Key Words. Cincinnati; Environmental Benefits; Hedonics; Ohio; Property Value; Urban Forestry.
\end{abstract}

Environmental benefits of the urban forest include improved air quality, energy conservation, climate moderation, flood control, stormwater mitigation, wildlife habitat, and reduction of noise levels (Dwyer et al. 1992). Trees help reduce stress and improve the physical health of urbanites. Research among hospital patients found that patients with a view of from their hospital recovery room of greenspace that included trees were on average discharged from the hospital sooner, and required less pain management medication than hospital patients recovering in rooms without windows or with windows that did not have a view of greenspace (Ulrich 1984). In studies that compare quality of life issues in public housing units in Chicago, Illinois, U.S., Kuo (2003) reports a significant correlation between residents' access to greenspace with trees and turf and lower rates of crime, suggesting that the quality of the landscaping in neighborhoods may affect variables such as communication between residents, frequency of people occupying outdoor spaces, and how such strengthening of social ties can affect crime. Despite the many benefits of the urban forest, financial support for urban forestry programs is on the decline (Hauer and Johnson 2008).

Previous research in the United States and Europe has shown varying impact of trees on property values. Environmental, economic, and social factors affect willingness to pay for trees and therefore impacts vary from country to country, and even region to region, within the United States. For this research, data were collected during summer months when deciduous tree canopy was present, as well as during winter months with the absence of deciduous tree cover. A model was devel- oped to determine if home sale prices were affected by the presence or absence of tree cover.

The six neighborhoods studied were of varying economic backgrounds. Differences in education and income were theorized to be determining factors in a person's willingness to pay for tree cover. A model was developed to evaluate differences in the value of tree cover among the six neighborhoods.

Hedonic price studies, regression modeling, as well as various qualitative methods have been used to study both the effects of generally positive variables (such as proximity to golf courses) and generally negative variables (such as proximity to leaking underground storage tanks) on property values (Faber 1998; Simons et al. 1999; Boyle and Kiel 2001). Hedonics is a method of non-market valuation (Freeman 2003). In this study, hedonics was used to estimate the monetary value of tree cover as an environmental asset. This method assumes that differences in property prices are due to differences in housing characteristics. Property prices should reflect the extra money people are willing to pay for an environmental asset such as trees (Tyrväinen 1997). This method relates the market price of a good, typically housing, to the set of characteristics that define it. The monetary value of each characteristic can be calculated by observing the differences in the market price of commodities sharing the same attributes (Morancho 2003). The price paid for a good is considered to be the sum of the price paid for each characteristic (Morancho 2003). A hedonic model can be computed from data about prices and property attributes. Implicit prices for different housing characteristics are estimated by multiple regression analyses (Tyrväinen 1997).

The objective of this research was to evaluate the impact trees have on property values of six distinct commu- 
nities of varying socioeconomic levels in the city of Cincinnati, Ohio, U.S. It was hypothesized that tree cover would have a positive effect on the sale price of homes.

\section{METHODS AND MATERIALS}

This study was conducted within six communities in Cincinnati, Ohio. These six communities are of varying socioeconomic backgrounds and include Bond Hill, Carthage, Clifton, Hyde Park, Kennedy Heights, and North Avondale. Most of the properties in these areas are 60- to 80-yearold single-family homes on small urban lots. More affluent areas, such as Clifton and Hyde Park, have some properties with larger lots. For this study, apartment buildings were excluded, as well as sales at non-market prices. Tax assessor records were obtained from home sales between the years 2000 and 2005. One hundred property sales were randomly selected from each of the six communities. The initial data was collected during the winter when the deciduous foliage was not present. Dominant genus, caliper of dominant genus, estimate of percent tree cover, and overall property maintenance was recorded. Researchers also noted whether the dominant genus was evergreen or deciduous. The data collection was repeated during the summer months when trees were in full canopy. All trees were included in the data collection for both summer and winter evaluations.

For data collection, a physical inspection and assessment of each of the 600 properties was performed. All trees were inventoried. Dominant genus was also determined by assessment of most prevalent canopy cover and noted as to deciduous or evergreen. For this analysis, baldcypress (Taxodium distichum) and dawn redwood (Metasequoia glyptostroboides) were classified as deciduous and American holly (Ilex opaca) was considered an evergreen. For simplified analysis, deciduous genera were recorded as zero and evergreen genera recorded as one. Caliper of dominant genus was noted. The number of trees on the property was recorded. Canopy cover was then estimated by ocular estimate. If the canopy of a tree on an adjacent property overhung the property being inspected, this tree canopy was included in the estimate of cover but not included in the tree count. Only trees planted on the property or street trees on the property easement were included in the tree count.

Property maintenance was recorded on a scale of 1 to 5 , with 5 being the best. A property was given a rating of 3 if it was on par with the average maintenance level of its neighborhood, a rating of 4 if it was above average, and a rating of 5 if maintenance was exceptional. A property received a rating of 2 if it was below average and 1 if the property was in total disrepair. This was an assessment of the general upkeep of the exterior of the home and yard.

Finally, impact of the landscape was assessed on a scale of 1 to 5 , with 1 being poor and 5 being excellent. The quality of the landscape design, plantings, and maintenance of the plantings was evaluated. This rating method was similar to the property maintenance rating, with 3 given to properties on par with their neighbors, 4 as above average and 5 for exceptional properties. Again, 2 was given to properties below average and 1 given to overgrown, poorly landscaped sites. Tree health and structure along with placement were considered when rating impact.
Property maintenance and landscape impact were found to be highly correlated; therefore only property maintenance was considered when developing the hedonic model.

The six hundred properties, 100 from each of the six communities, were first evaluated in the winter of 2005-2006. The following property characteristics were selected as the explanatory variables: sale date: number of days on market prior to sale, square footage: size of living space in square feet, number of acres: lot size in acres, number of bedrooms, style height: one story or two story, year built: house age in years, baths: assigned 1 point for a whole bath and 0.5 point for a half bath, cover: estimated percentage of tree cover, and neighborhood (Hyde Park, Kennedy Heights, Clifton, Carthage, or North Avondale; coded $1=$ yes, $0=$ no).

The community of Bond Hill was held constant while the other five communities-Hyde Park, Kennedy Heights, Clifton, Carthage, and North Avondale-were variables in the model (Table 1). This allowed a comparison of the differences in the communities relative to Bond Hill.

Evaluation of the six hundred properties was repeated in the late spring and summer of 2006 when the tree canopy was in full cover. A second evaluation was performed to determine if full canopy added more value than a winter site with no leaf cover. The community of Bond Hill was held constant, while the other five communities were variables in the model (Table 2).

Table 1. Results of the analysis of the winter data. Data collected winter 2005-2006 in the Cincinnati, Ohio, communities of Bond Hill, Carthage, Clifton, Hyde Park, Kennedy Heights, and North Avondale. $R^{2}=0.681$, adjusted $R^{2}=0.674$, F-value $=96.29, \mathrm{n}=600$.

\begin{tabular}{llll}
\hline Variable & Coefficient & t-ratio & $P$-value \\
\hline Sale date & 12.35 & 3.2 & 0.0015 \\
Square footage & 37.11 & 6.28 & $<0.0001$ \\
\# acres & 170,457 & 7.35 & $<0.0001$ \\
\# bedrooms & $4,298.29$ & 1.07 & 0.286 \\
Style height & $-10,708$ & -1.22 & 0.2244 \\
Year built & 481.47 & 2.75 & 0.0062 \\
Total baths & 30,328 & 5.52 & $<0.0001$ \\
Tree cover & 561.2 & 2.91 & 0.0037 \\
Hyde Park & 161,315 & 13.89 & $<0.0001$ \\
Kennedy Heights & $-1,561.78$ & -0.14 & 0.8918 \\
Clifton & 95,447 & 7.78 & $<0.0001$ \\
Carthage & 308.01 & 0.03 & 0.9793 \\
North Avondale & $6,789.17$ & 0.54 & 0.588 \\
\hline
\end{tabular}

Note: Sale date: number of days on market prior to sale; square footage: size of living space in square feet; number of acres: lot size in acres, number of bedrooms, style height: one story or two story; year built: house age in years; baths: assigned 1 point for a whole bath and 0.5 point for a half bath; cover: estimated percentage of tree cover; and neighborhood (Hyde Park, Kennedy Heights, Clifton, Carthage, or North Avondale; coded $1=$ yes, $0=$ no).

The hedonic method was utilized to estimate the value of each of the property attributes, including tree cover. A hedonic model can be computed from data about property prices and attributes. Implicit prices for different housing characteristics are estimated by multiple regression analyses. Attributes such as square footage and lot size are held constant while evaluating the effect of another variable such as tree cover.

The monetary value of each characteristic can be calculated by observing the difference in the market price of commodities sharing the same attributes (Morancho 
Table 2. Results of the analysis of summer data. Data collected in summer 2006 in the Cincinnati, Ohio, communities of Bond Hill, Carthage, Clifton, Hyde Park, Kennedy Heights, and North Avondale. $R^{2}=0.681$, adjusted $R^{2}=0.674$, F-value $=96.40, \mathrm{n}=600$.

\begin{tabular}{llll}
\hline Variable & Coefficient & t-ratio & $P$-value \\
\hline Sale date & 12.11 & 3.13 & 0.0018 \\
Square footage & 44.67 & 6.75 & $<0.0001$ \\
\# acres & 159,457 & 6.6 & $<0.0001$ \\
Style height & $-6,655.4$ & -0.76 & 0.4495 \\
Total rooms & $-4,261.16$ & -1.72 & 0.0851 \\
Year built & 450.33 & 2.56 & 0.0106 \\
Total baths & 34,512 & 6.17 & $<0.0001$ \\
Tree cover & 580.92 & 2.6 & 0.0096 \\
Hyde Park & 162,410 & 13.93 & $<0.0001$ \\
Kennedy Heights & $3,900.08$ & 0.34 & 0.7333 \\
Clifton & 99,023 & 8.05 & $<0.0001$ \\
Carthage & $-2,038.77$ & -0.17 & 0.8636 \\
North Avondale & 12,360 & 0.98 & 0.3265 \\
\hline
\end{tabular}

Note: Sale date: number of days on market prior to sale; square footage: size of living space in square feet; number of acres: lot size in acres, number of bedrooms; style height: one story or two story; year built: house age in years; baths: assigned 1 point for a whole bath and 0.5 point for a half bath; cover: estimated percentage of tree cover; and neighborhood (Hyde Park, Kennedy Heights, Clifton, Carthage, or North Avondale; coded $1=$ yes, $0=$ no).

2003). It is theorized that goods are defined by the set of characteristics that form them and the price paid for that good is the sum of the price paid for each characteristic of that good (Morancho 2003). This is written as follows:

$$
P=f\left(x_{1}, x_{2}, x_{3}, x_{\mathrm{n}}, z\right)
$$

where $\mathrm{P}$ is the market price of the property and $x_{1}, x_{2}, x_{3}$, $\ldots x_{\mathrm{n}}$ represent the property characteristics, such as square footage and number of bathrooms. Tree cover, the environmental attribute evaluated in this study, is expressed as $z$. The environmental variable without a market price is referred to as the hedonic variable (Morancho 2003).

Linear models have been used in previous hedonic research (Tyrväinen 1997; Morancho 2003). Linear models are in use due to their ease of interpretation, although there are many reasons to believe price and the environmental variable may be non-linear (Morancho 2003). A linear model assumes that the marginal willingness to pay for an additional unit of an attribute (e.g., an extra percentage of tree cover) remains constant. In developing the model for this analysis, a quadratic model tested tree cover and age of the properties; they were not found to be significant.

The basic regression analysis equation is as follows:

$$
P_{\mathrm{i}}=b_{1} x_{1 \mathrm{i}}+b_{2} x_{2 \mathrm{i}}+b_{3} x_{3 \mathrm{i}}+\ldots+b_{\mathrm{n}} x_{\mathrm{ni}}+b_{\mathrm{z}} z_{\mathrm{i}}+\varepsilon_{\mathrm{i}}
$$

where $x_{1 \mathrm{i}}, x_{2 \mathrm{i}}, \ldots, x_{\mathrm{ni}}, z_{\mathrm{i}}$ are the housing variables, parameters $b_{1}, b_{2}, \ldots, b_{\mathrm{n}}, b_{\mathrm{z}}$ are the marginal willingness to pay for each of the property attributes, and $\varepsilon_{\mathrm{i}}$ is the error term for the equation.

The property transactions selected for this research occurred over a five-year period, between 2000 and 2005. Sale prices were adjusted to third quarter 2007 prices of the Home Price Index for the Cincinnati Metropolitan Statistical Area.

\section{RESULTS AND DISCUSSION}

\section{Winter Results}

In developing the model it was found that tree cover and the impact (maintenance) rating were closely correlated. Maintenance rating and landscape impact rating were also closely correlated. Landscape rating was dropped from the model and maintenance rating was used for further testing. When using both variables in the same model, tree cover lost its significance. The model was run using both tree cover and the impact rating separately and each was found to be significant if used individually. Both models had the same $\mathrm{R}^{2}$ value and since the impact rating is a subjective variable, tree cover was chosen for the model and is an accepted method for reducing covariates when using the hedonic method. When developing a hedonic equation, it is important to use a minimum number of variables as to prevent problems with multicollinearity. Multicollinearity may cause problems such as imprecise estimates and wrong sign on variables even though the $\mathrm{R}^{2}$ may be high (Hanley and Spash 1993).

The winter set of explanatory variables accounts for $68 \%\left(\mathrm{R}^{2}\right.$ $=0.681)$ of the variation in housing price $(P \leq 0.05)$ (Table 1$)$. The variable coefficients indicate that location of the house, such as the Hyde Park variable, had the greatest explanatory power, with the Clifton variable following second in explanatory power (Table 1). Number of acres, living square footage, total number of baths, sales date, tree cover, and year built had the remainder of the explanatory power, listed in rank order. Sale date variable was included to show that the fewer days a property is on the market, the more value was added to the property. All coefficient signs were positive as expected. The other three neighborhoods-Kennedy Heights, Carthage, and North Avondalewere not significantly different from the constant, Bond Hill.

Results of this research indicate that living in Hyde Park or Clifton has the largest positive impact on the price of a home. Analysis also shows an increase of USD \$170,457 for each additional acre, but since most of the properties studied are on small urban lots, the value of the land, although still an important factor influencing price, is typically only a fraction of the per acre amount. Results also indicate that tree cover has a significant positive effect on home values in the six communities studied. The average effect of tree canopy across all communities indicates an increase of $\$ 561$ per one percent increase in tree cover. The mean property value for the 600 sites studied was $\$ 166,357$, while the mean percentage of tree cover was $24.8 \%$. This indicates that the average value of tree canopy is $\$ 13,913$ or $8.4 \%$ of the sale price of the home as determined by the data collected during the winter months. These results are in line with previous findings. Morales (1980) found that good tree cover in Manchester, Connecticut, U.S., increased property values by six percent, while in a smaller study (Martin et al. 1989), tree cover in Austin, Texas, U.S., increased property values as much as $19 \%$. In more recent studies, trees were also found to increase property values in Minnesota, U.S. (Sander et al. 2010) and Indiana, U.S. (Payton et al. 2008). Another study in Los Angeles, California, U.S., found residents would like additional trees but were not willing to pay for them (Saphores and Li 2012). 


\section{Summer Results}

This set of explanatory variables accounts for $68 \%\left(\mathrm{R}^{2}=0.681\right)$ of the variation in housing price $(P \leq 0.05)$ (Table 2$)$. The variable coefficients from the summer data also indicate that the Hyde Park location had the greatest impact on property values. The Clifton location had the second highest impact followed, in order, by square footage of living space, number of acres, total number of baths, sale date, tree cover, and year built. The coefficient signs of all significant variables were positive, as expected.

Summer results were very similar to the winter results with location of the property being the most important factor in determining sales price home. The summer results indicated that the price per square foot of living space was seven U.S. dollars lower than winter results and the cost per acre was $\$ 11,000$ higher. Winter analysis found the number of bedrooms was the best fit, while summer analysis used the total number of rooms as the best fit. Possible explanations for these differences may include the large number of sites evaluated, changes in tree cover, such as tree plantings or loss, and variation associated with visual estimations of tree cover.

As with the winter results, summer results indicate that tree canopy is important to home buyers in these communities. The average effect of tree canopy across all communities indicates that for each percentage increase of tree cover, sales price increased by $\$ 580.92$. The mean property value for the 600 sites analyzed was $\$ 166,357$, while the mean percentage of tree cover was $27.1 \%$. This indicates that the average value of tree canopy across the 600 properties was $\$ 15,743$ or $9.5 \%$ of the summer sale price of the home

\section{Combined Evaluations}

The decision to purchase a property is often decided a number of weeks ahead of the actual closing date. It takes time to secure financing, conduct property inspections, and possibly sell another house. The average length of time between contract signing and the actual closing date is approximately 45-60 days (Abel 2008). In order to determine if this had an influence on the significance of tree cover both the winter data and the summer data were combined and 60 days was subtracted from the actual closing date. If estimated date of signing fell between November 1st and April 30th the contract date was considered winter. If the signing date fell between May 1st and October 31st it was considered a summer contract. Since two sets of data were collected for each property the set of data that did not fall into the actual contract signing time was dropped from the analysis so the total number of observations remained 600 properties.

The cover variable represents the baseline actual cover present and visible when houses were sold in the summer. For houses sold in the winter, the cover-winter variable is an adjustment to this baseline to reflect that the canopy was still present, but had less visual impact.

The combined set of explanatory variables accounts for $69 \%$ $\left(\mathrm{R}^{2}=0.686\right)$ of the variation in sale price of the properties $(P \leq$ $0.05)$ (Table 3 ). The variable coefficients indicate that the Hyde Park variable had the greatest explanatory power followed by the Clifton variable. The remainder of the significant variables, in rank order, included number of acres, living square footage, total number of baths, summer tree cover, and year built. The coefficient sign for all significant variables was positive.

Analysis found that the effect of tree cover for summer sales was an increase in sale price of $\$ 780$ per one percent of tree cover. The winter sales adjustment was a decline of $\$ 111$ per one percent
Table 3. Results of the analysis of the combination of summer and winter data. Data collected in 2005-2006 in the Cincinnati, Ohio, communities of Bond Hill, Carthage, Clifton, Hyde Park, Kennedy Heights, and North Avondale. $\mathrm{R}^{2}=0.686$, adjusted $R^{2}=0.678, F-$ value $=91.23, n=600$.

\begin{tabular}{llll}
\hline Variable & Coefficient & t-ratio & $P$-value \\
\hline Sale date & 1.21 & 0.29 & 0.7752 \\
Square footage & 41.15 & 6.35 & $<0.0001$ \\
\# acres & 190,977 & 7.47 & $<0.0001$ \\
\# bedrooms & $4,639.63$ & 1.05 & 0.2932 \\
Style height & $-9,441.05$ & -0.98 & 0.3291 \\
Year built & 583.3 & 3.03 & 0.0025 \\
Total baths & 33,210 & 5.53 & $<0.0001$ \\
Tree cover & 783.98 & 3.14 & 0.0018 \\
Cover winter & -111.27 & -0.47 & 0.6385 \\
Hyde Park & 183,574 & 14.38 & $<0.0001$ \\
Kennedy Heights & -384.22 & -0.03 & 0.9756 \\
Clifton & 109,657 & 8.12 & $<0.0001$ \\
Carthage & $-2,754.67$ & -0.21 & 0.8322 \\
North Avondale & $9,935.87$ & 0.72 & 0.4714 \\
\hline
\end{tabular}

Note: Sale date: number of days on market prior to sale; square footage: size of living space in square feet; number of acres: lot size in acres; number of bedrooms; style height: one story or two story; year built: house age in years; baths: assigned 1 point for a whole bath and 0.5 point for a half bath; cover: estimated percentage of tree cover; and neighborhood (Hyde Park, Kennedy Heights, Clifton, Carthage, or North Avondale; coded $1=$ yes, $0=$ no)

of tree cover. This adjustment would be interpreted as one percent of tree cover adds $\$ 669(\$ 780-\$ 111=\$ 669)$ to the winter sale price but the cover winter variable was not significant. The effects of tree cover for winter and summer sales are not significantly different from one another. There may be a slight tendency for cover to add less value for winter sales, but its effect is weak at best. The possible explanation may be that home buyers cannot visualize tree canopy accurately without the leaf cover being present.

The average effect of tree canopy across all six communities was an increase of $\$ 783.98$ per one percent increase in tree cover. The mean sale price across the 600 sites was $\$ 188,730$, with the mean canopy cover of $25.8 \%$. This indicates the average value of tree canopy is $\$ 20,226$ or $10.7 \%$ of the sale price of the home. All monetary values in this model are reflected in 2007 prices. Again, this value is consistent with previous findings.

\section{Testing for Quadratic Effects}

A model was developed to determine if there was significant concavity to the effect of tree cover on sale price. If the model indicated a quadratic relationship, then the optimal percentage of tree cover could be determined. This model indicates that there does not seem to be significant concavity to the effects of tree cover (Table 4). The explanatory variables account for $69 \%\left(\mathrm{R}^{2}=0.686\right)$ of the variation in this model $(P \leq 0.05)$ (Table 4). Living space square footage, number of acres, total number of baths, along with the two communities of Hyde Park and Clifton were found to be significant in determining sales price. The year built was also insignificant for concave effects. The relationship between tree cover and sales price appears to be approximately linear. There does not seem to be an optimal percentage of tree cover.

\section{Evergreen Versus Deciduous}

Previous research has indicated that homeowners do not seem to have a preference for evergreen species over deciduous species of 
trees (Anderson and Cordell 1988). In order to determine if this was the case in the six communities studied, a model was developed to test for these preferences. Dominant genus information was collected during the on-site property inspections. For use in the analysis, dominant deciduous trees were indicated with the number zero and dominant evergreen trees were indicated by the number one.

The set of explanatory variables accounted for $69 \%$ $\left(\mathrm{R}^{2}=0.685\right)$ of the variation in this model (Table 5). Consistent with the previous models, living in Hyde Park and Clifton have the greatest influence on sale price. The deciduous versus evergreen variable was not found to be significant. These finding are consistent with previous research.

Table 4. Results of the analysis of quadratic effects. $R^{2}=0.686$, adjusted $\mathrm{R}^{2}=0.678, \mathrm{~F}$-value $=85.07, \mathrm{n}=600$.

\begin{tabular}{llll}
\hline Variable & Coefficient & t-ratio & $P$-value \\
\hline Sale date & 1.36 & 0.32 & 0.7481 \\
Square footage & 41.4 & 6.38 & $<0.0001$ \\
\# acres & 191,349 & 7.44 & $<0.0001$ \\
\# bedrooms & $4,640.82$ & 1.05 & 0.2939 \\
Style height & $-9,453.68$ & -0.98 & 0.3283 \\
Year built & 14,618 & 0.76 & 0.4468 \\
Year built 2 & -3.62 & -0.73 & 0.465 \\
Total baths & 33,800 & 5.59 & $<0.0001$ \\
Tree cover & 634.77 & 0.9 & 0.37 \\
Tree cover 2 & 1.03 & 0.1 & 0.918 \\
Hyde Park & 184,551 & 14.4 & $<0.0001$ \\
Kennedy Heights & 402.29 & 0.03 & 0.9745 \\
Clifton & 111,461 & 8.18 & $<0.0001$ \\
Carthage & $1,131.09$ & 0.08 & 0.936 \\
North Avondale & 10,511 & 0.76 & 0.4452 \\
\hline
\end{tabular}

Note: Sale date: number of days on market prior to sale; square footage: size of living space in square feet; number of acres: lot size in acres; number of bedrooms; style height: one story or two story; year built: house age in years; baths: assigned 1 point for a whole bath and 0.5 point for a half bath; cover: estimated percentage of tree cover; and neighborhood (Hyde Park, Kennedy Heights, Clifton, Carthage, or North Avondale; coded $1=$ yes, $0=$ no).

Table 5. Results of the analysis of evergreen versus deciduous trees on property values of the Cincinnati, Ohio, communities of Bond Hill, Carthage, Clifton Hyde Park, and North Avondale. $R^{2}=0.686$, adjusted $R^{2}=0.678, F-v a l u e=88.45, n=600$.

\begin{tabular}{llll}
\hline Variable & Coefficient & t-ratio & $P$-value \\
\hline Sale date & 1.68 & 0.38 & 0.7038 \\
Square footage & 40.02 & 6.04 & $<0.0001$ \\
\# acres & 190,337 & 7.34 & $<0.0001$ \\
\# bedrooms & $4,878.77$ & 1.08 & 0.2805 \\
Style height & $-9,165.72$ & -0.93 & 0.3551 \\
Year built & 558.5 & 2.81 & 0.0052 \\
Total baths & 33,506 & 5.44 & $<0.0001$ \\
Tree cover & 746.31 & 3.1 & 0.0021 \\
Deciduous/evergreen & -840.86 & -0.09 & 0.9283 \\
Hyde Park & 186,087 & 14.21 & $<0.0001$ \\
Kennedy Heights & 886.95 & 0.07 & 0.9449 \\
Clifton & 115,042 & 8.27 & $<0.0001$ \\
Carthage & -3027.3 & -0.22 & 0.8232 \\
North Avondale & 12,556 & 0.9 & 0.3709 \\
\hline
\end{tabular}

Note: Sale date: number of days on market prior to sale; square footage: size of living space in square feet; number of acres: lot size in acres; number of bedrooms; style height: one story or two story; year built: house age in years; baths: assigned 1 point for a whole bath and 0.5 point for a half bath; tree cover: estimated percentage of tree cover; deciduous/evergreen: determined for each plant on property, and neighborhood (Hyde Park, Kennedy Heights, Clifton, Carthage, or North Avondale; coded $1=$ yes, $0=$ no)

\section{Genus}

Research has determined that people have preferences for tree size (Kalmbach and Kielbaso 1979; Hitchmough and Bonugli 1997; Heimlich et al. 2008) and tree shape (Sommer and Summit 1996; Sommer 1997). Italian and Portuguese immigrants to North America were found to have preferences for fruit tree species (Fraser and Kenney 2000). In the interest of determining if citizens of the six Cincinnati communities had a preference for tree genera, a model was developed to assess their preferences.

During the on-site inspection, dominant genus, as determined by assessment of most prevalent canopy cover, was noted for each of the 600 properties. Over 40 different genera of trees were found to be dominant on the 600 properties. Although there were many genera, some were very common while others were only noted on a few properties. The six top genera were chosen as they represented the majority of trees in the communities and it was thought that using genera with only a few properties represented would not be valid. The six most common genera in the study, with quantities, include Acer (128), Quercus (126), Picea (64), Pinus (41), Malus (33), and Pyrus (30).

Analysis indicated that the genus of a tree was not important to property owners in the communities studied. The model captured $69 \%\left(\mathrm{R}^{2}=0.688\right)$ of the variation in sales price $(P \leq$ 0.05 ). Residents of these six communities are willing to pay for trees on the property but do not seem to have a preference for a specific type of tree. Most homeowners are probably not knowledgeable of the specific qualities of the various tree genera. This study also found that the number of trees on a property, as well as caliper of dominant species, was not significant.

\section{Neighborhoods}

The six neighborhoods-Bond Hill, Carthage, Clifton, Hyde Park, Kennedy Heights, and North Avondale-vary from one another demographically. Hyde Park is the most affluent, with a median household income of $\$ 59,541$, while Carthage has the lowest median household income of $\$ 27,364$ (Table 7). Hyde Park also ranks number one in college education with $69.5 \%$ of its residents possessing a bachelor's degree or higher (Table 7). Carthage ranks lowest in college education with only nine percent of its residents possessing a four-year degree (Table 7). With differences in education, income, and household family status there is likely to be differences in attitudes about trees. A model was developed to determine if these six neighborhoods varied significantly in their willingness to pay for trees (Table 6).

As in previous models, living in Hyde Park and Clifton are important in determining the sale price of a property (Table 6). The explanatory variables in this model explained $70 \%$ of the variation in price $\left(\mathrm{R}^{2}=0.697\right)(P \leq 0.05)$ (Table 6). Lot size, living square footage, number of baths, and the year the home was built were also found to be significant.

Tree cover seems to be valued more in Hyde Park and North Avondale where it had a significant effect on property values (Table 6). The $P$-value for cover in Clifton was 0.118 , which may indicate that cover has a weak effect in determining sale price in this community. The cover effect in Bond Hill, which was the constant, Carthage and Kennedy Heights is very close to zero and may have a slightly negative effect on sale price. 


\section{SUMMARY}

Results of this research indicate that tree cover has an overall positive monetary effect on the sale price of homes in the six Cincinnati, Ohio, communities studied. From the coefficients derived from the analysis, it was estimated that the average value of tree canopy is $\$ 20,226$ or $10.7 \%$ of the total sale price of the homes observed.

The effects of winter and summer cover were not significantly different from one another. There may be a slight tendency for tree cover to add less value during the winter months but the effect is weak.

Results of this study found differences among the communities with respect to the value placed on trees. Tree cover seems to be valued more in Hyde Park and North Avondale where it had a significant effect on property values. These two communities also had the highest household median income of $\$ 59,541$ and $\$ 39,297$, respectively. Results of the analysis may also indicate that tree cover has a weak effect on property values in Clifton. Although the recorded median household income of Clifton was

Table 6. Results of the analysis of the effect of neighborhood tree cover on the property values of the Cincinnati, Ohio, communities of Bond Hill, Carthage, Clifton, Hyde Park, Kennedy Heights, and North Avondale. $R^{2}=0.698$, adjusted $R^{2}=0.689$, F-value $=74.58, n=600$

\begin{tabular}{llll}
\hline Variable & Coefficient & t-ratio & $P$-value \\
\hline Sale date & 1.3 & 0.31 & 0.7557 \\
Square footage & 42.19 & 6.6 & $<0.0001$ \\
\# acres & 176,772 & 6.84 & $<0.0001$ \\
\# bedrooms & $5,062.71$ & 1.17 & 0.2444 \\
Style height & $-6,516.76$ & -0.68 & 0.4955 \\
Year built & 555.36 & 2.9 & 0.0038 \\
Total baths & 31722 & 5.33 & $<0.0001$ \\
Cover & -115.43 & -0.22 & 0.8241 \\
Hyde Park cover & $1,728.78$ & 2.16 & 0.0312 \\
Kennedy Heights cover & -156.55 & -0.21 & 0.8358 \\
Clifton cover & $1,141.82$ & 1.56 & 0.1183 \\
Carthage cover & -123.14 & -0.16 & 0.8713 \\
North Avondale cover & $2,612.41$ & 3.59 & 0.0004 \\
Hyde Park & 141,108 & 6.06 & $<0.0001$ \\
Kennedy Heights & $8,006.82$ & 0.33 & 0.7415 \\
Clifton & 80,259 & 3.45 & 0.0006 \\
Carthage & $-2,029.04$ & -0.09 & 0.9277 \\
North Avondale & $-56,953$ & -2.45 & 0.0147 \\
\hline
\end{tabular}

Note: Sale date: number of days on market prior to sale; square footage: size of living space in square feet; number of acres: lot size in acres; number of bedrooms; style height: one story or two story; year built: house age in years; baths: assigned point for a whole bath and 0.5 point for a half bath; cover: estimated percentage of tree cover; and neighborhood (Hyde Park, Kennedy Heights, Clifton, Carthage, or North Avondale; coded $1=$ yes, $0=$ no).
$\$ 32,548$, this number may be skewed downward due to the fact that the University of Cincinnati is located in Clifton. Clifton is home to many students who may affect median income values. Residences of Hyde Park and Clifton were the most educated, with North Avondale ranking third among the six communities. Tree cover was not significant in the communities of Bond Hill, Carthage, and Kennedy Heights. This was a surprise. Although the study authors expected there to be a lower impact in less affluent communities, there were still expectations of some positive effect on property values. It may be interesting to include a homeowner survey as part of future research. Financial factors may play a role in determining a willingness to pay for treed property.

Trees have a positive effect on property values in the more affluent communities studied. Results of this study may encourage homeowners to plant trees on their property and provide financial support to local community forestry projects.

\section{LITERATURE CITED}

Abele, J. 2008. Multiple Listing Service, Cincinnati, Ohio. Personal communications.

Anderson, L.M., and H.K. Cordell. 1988. Influences of trees on residential property values in Athens, Georgia (U.S.A): A survey based on actual sales prices. Landscaping and Urban Planning 15:153-164.

Boyle, M., and K. Kiel. 2001. A Survey of house price hedonic studies of the impact of environmental externalities. Journal of Real Estate Literature 9(2):116-44.

Dwyer, J.F., E.G. McPherson, H.W. Schroeder, and R.W. Rowntree. 1992. Assessing the benefits and costs of the urban forest. Journal of Arboriculture 18:227-234.

Faber, S. 1998. Undesirable facilities and property values: A summary of empirical studies. Ecological Economics 24:1-14.

Fraser, E.D.G., and W.A. Kennedy. 2000. Cultural background and landscape history as factors affecting perceptions of the urban forest. Journal of Arboriculture 26(2):106-113.

Freeman, A.M. 2003. The Measurement of Environmental and Resource Values, Theory and Methods, 2nd edition.

Hanley, N., and C.L. Spash. 1993. Cost-Benefit Analysis and the Environment. Northampton, Massachusetts, U.S.: Edward Elgar.

Hauer, R.J., and G.R. Johnson. 2008. State urban and community forestry program funding, technical assistance, and financial assistance within the 50 United States. Arboriculture \& Urban Forestry 34(5):280-289.

Heimlich, J., T.D. Sydnor, M. Bumgardner, and P. O'Brien. 2008. Attitudes of residents toward street trees on four streets in Toledo, Ohio, U.S., before removal of ash trees (Fraxinus spp.) from emerald ash borer (Agrilus planipennis). Arboriculture \& Urban Forestry 34(1):47-53.

Table 7. Demographics of six Cincinnati, Ohio, neighborhoods. Information obtained from 2000 U.S. Census. Currency is represented in U.S. dollars.

\begin{tabular}{lllll}
\hline Neighborhood & Population & $\begin{array}{l}\text { Median } \\
\text { household } \\
\text { income }(\$)\end{array}$ & $\begin{array}{l}\% \text { of families } \\
\text { below poverty } \\
\text { level }\end{array}$ & $\begin{array}{l}\%>25 \text {-years-old with } \\
\text { bachelor's degree or } \\
\text { greater }\end{array}$ \\
\hline Bond Hill & 9,682 & 28,543 & $20 \%$ & $9.4 \%$ \\
Carthage & 2,412 & 27,364 & $12 \%$ & $9.3 \%$ \\
Clifton & 8,546 & 32,548 & $7 \%$ & $61.0 \%$ \\
Hyde Park & 13,640 & 59,541 & $2 \%$ & $23.5 \%$ \\
Kennedy Heights & 5,689 & 32,882 & $7 \%$ & $36.6 \%$ \\
North Avondale & 6,326 & 39,297 & $8 \%$ & $2 \%$ \\
\hline
\end{tabular}

Note: Sale date: number of days on market prior to sale; square footage: size of living space in square feet; number of acres: lot size in acres; number of bedrooms; style height: one story or two story; year built: house age in years; baths: assigned 1 point for a whole bath and 0.5 point for a half bath; cover: estimated percentage of tree cover; and neighborhood (Hyde Park, Kennedy Heights, Clifton, Carthage, or North Avondale; coded 1 = yes, 0 = no). 
Hitchmough, J.D., and A.M. Bonugli. 1997. Attitudes of a medium sized town in southwest Scotland to street trees. Landscape Research 22:327-337.

Kalmbach, K.L., and J.J. Kielbaso. 1979. Resident attitudes toward selected characteristics of street tree plantings. Journal of Arboriculture 5(6): 124-129.

Kuo, F.E. 2003. The role of arboriculture in a healthy social ecology. Journal of Arboriculture 29(3):148-155.

Martin, C.W., R.C. Maggio, and D.N. Appel. 1989. The contributory value of trees to residential property in the Austin, Texas metropolitan area. Journal of Arboriculture 15(3):72-76.

Morales, D.J. 1980. The Contribution of Trees to Residential Property Value. Journal of Arboriculture 6(11):305-308.

Morancho, A.B. 2003. A hedonic valuation of urban green areas. Landscape and Urban Planning 66:35-41.

Payton, S., G. Lindsey, J. Wilson, J. Ottensmann, and J. Man. 2008. Valuing the benefits of the urban forest: A spatial hedonic approach. Journal of Environmental Planning and Management 51(6):717-736.

Sander, H., S. Polasky, and R.G. Haight. 2010 The value of urban tree cover: A hedonic property price model in Ramsey and Dakota Counties, Minnesota, USA. Ecological Economics 69:1646-1656.

Saphores, J., and W. Li. 2012. Estimating the value of urban green areas: A hedonic pricing analysis of the single family housing market in Los Angeles, CA. Landscape and Urban Planning 104:373-387.

Simons, R.A., W. Bowen, and A. Sementelli. 1999. The price and liquidity effects of UST leaks from gas stations on adjacent contaminated property. The Appraisal Journal April:186-94.

Sommer, R., and J. Summit. 1996. Cross-national rankings of tree shape. Ecological Psychology 8(4):327-341.

Sommer, R., 1997. Further cross-national studies of tree form preference. Ecological Psychology 9(2):153-160.

Tyrväinen, L. 1997. The amenity value of the urban forest: An application of the hedonic pricing method. Landscape and Urban Planning 37:211-222.

Ulrich, R.S. 1984. View through a window may influence recovery from surgery. Science 224:420-421.

U.S. Census Bureau. 2000. Profile of Selected Economic Characteristics, Cincinnati, Ohio. <http://factfinder.census.gov>

Kelley C. Dimke

Dept. of Horticulture and Crop Science

2021 Coffey Road

The Ohio State University

Columbus, Ohio 43210-1086, U.S.

T. Davis Sydnor, School of Natural Resources

2021 Coffey Road

The Ohio State University

Columbus, Ohio 43210-1086, U.S.

David S. Gardner (corresponding author)

Dept. of Horticulture and Crop Science

2021 Coffey Road

The Ohio State University

Columbus, Ohio 43210-1086, U.S.
Zusammenfassung. Der Wert des urbanen Forstes als eine Komponente der urbanen Umwelt. Bäume liefern für den Stadtbewohner sowohl umweltbezogene wie auch soziale Vorteile. In vielen Städten nimmt die finanzielle Unterstützung der urbanen Forstwirtschaft ab. Das Ziel dieser Studie lag darin, den Einfluss von Bäumen als Grundstücksbestandteil auf den Wert der Immobilie in sechs Kommunen (Bond Hill, Carthage, Clifton, Hyde Park, Kennedy Heights, and North Avondale) mit unterschiedlichen sozioökonomischen Schwellenwerten in Cincinnati, Ohio, U.S. zu bewerten. In den Jahren 2000 bis 2005 wurden die Aufzeichnungen der Steuerprüfer zu Grundstücksverkäufen herangezogen. Aus jeder der sechs Kommunen wurden zufällig 100 Standorte ausgewählt. Von jedem Standort wurden Daten in den Sommer- und Wintermonaten gesammelt. Die vorherrschende Gattung, der Durchmesser dieser Gattung, eine Schätzung zum Bedeckungsgrad und die Pflege des Grundstücks wurden aufgezeichnet. Für diese Analyse wurde der hedonische Ansatz verwendet. Der durchschnittliche Effekt der Baumkronenbedeckung betrug in allen sechs Kommunen ca. USD $\$ 780$ pro Prozent Zunahme an Baumkronenbedeckung. Der durchschnittliche Verkaufserlös für die 600 Standorte betrug USD \$188.730, die durchschnittliche Kronenbedeckung betrug 25,8\%. Das zeigt, dass der durchschnittliche Wert der Baumkronen USD \$20.226 oder 10,7\% des Verkaufspreises beträgt.

Resumen. El valor del bosque como un componente del medio ambiente urbano es significativo. Los árboles proveen beneficios tanto ambientales como sociales para los habitantes urbanos. En muchas ciudades el apoyo financiero para la silvicultura urbana está en declive. El objetivo de este trabajo fue evaluar el impacto que tienen los árboles en los valores de propiedades de seis comunidades (Bond Hill, Cartago, Clifton, Hyde Park Heights Kennedy y Avondale Norte) de diferentes niveles socioeconómicos en Cincinnati, Ohio, Estados Unidos. Se obtuvieron registros del asesor de impuestos por las ventas de propiedades entre los años 2000 y 2005. Un centenar de sitios fueron seleccionados al azar de cada una de las seis comunidades. Se recogieron datos de cada sitio durante el invierno, así como los meses de verano. Se registraron los géneros dominantes, calibre del género dominante, la estimación de la cubierta forestal y mantenimiento de la propiedad en general. Se empleó el método hedónico para este análisis. El efecto promedio (media) de la cobertura de la copa de los árboles en las seis comunidades registró un aumento de aproximadamente USD $\$ 780$ por uno por ciento de aumento en la cobertura del árbol. El precio de venta promedio a través de los 600 sitios fue $\$ 188,730$, y la cubierta de dosel promedio fue de $25,8 \%$. Esto indica que el valor promedio de las copas de los árboles es $\$ 20,226$ o el $10,7 \%$ del precio de venta de la casa. 